\title{
PENGARUH PERBANDINGAN ALMOND DAN EDAMAME TERHADAP KARAKTERISTIK SUSU ALMOND EDAMAME
}

\author{
The Effect of Almond and Edamame Ratio on The Characteristic of Almond Edamame Milk
}

\author{
${ }^{1}$ Novia Hasanah, ${ }^{2}$ I Dewa Gde Mayun Permana*, ${ }^{2}$ Ni Wayan Wisaniyasa \\ ${ }^{1}$ Mahasiswa Program Studi Ilmu dan Teknologi Pangan, Fakultas Teknologi Pertanian, Unud \\ ${ }^{2}$ Dosen Program Studi Ilmu dan Teknologi Pangan, Fakultas Teknologi Pertanian, Unud \\ Kampus Bukit Jimbaran, Badung-Bali
}

\begin{abstract}
This research aimed to determine the effect of almond and edamame characteristics against almond edamame milk and to determine the best ratio of almond and edamame to generate the best characteristic almond edamame milk. The experimental design of this research is using Completely Randomized Design (CRD) with five levels of ratio treatment almond and edamame, which are 100\%:0\%, 90\%:10\%, 80\%:20\%, 70\%:30\%, and 60\%:40\%. The treatment was repeated three times to obtain 15 experimental units. The obtained data analyzed by variance analysis, and the treatment affecting the observed parameters, the test continue with Duncan test. The result showed that the ratio of almond and edamame had a significant effect in protein content, fat content, total solids, viscosity, pH level, and the scoring test (color, flavor, and taste), but insignificantly on the hedonic test (color, flavor, taste, and overall acceptance) of almond edamame milk. The best almond edamame milk obtained from $60 \%$ of almond and $40 \%$ of edamame with $6.39 \%$ of protein content, $5.57 \%$ of fat content, $16.52 \%$ of total solid, 246.67 cPs of viscosity, $\mathrm{pH}$ 6.57 , the sensory test in color (hedonic) was liked, color (scoring) was very greenish-white, in flavor (hedonic) was rather liked, flavor (scoring) was rather typical of edamame, in taste (hedonic) was rather liked, taste (scoring) was rather typical of edamame, and overall acceptance was liked.
\end{abstract}

Keywords: almond, edamame, vegetable milk

\section{PENDAHULUAN}

Susu adalah cairan hasil sekresi kelenjar mamae dari mamalia, dengan fungsi utama sebagai sumber nutrisi bagi anaknya (Walstra et al., 2006). Warna susu yang normal adalah putih sedikit kekuningan, dan memiliki rasa sedikit manis serta bau (aroma) yang khas (Muhammad, 2002). Komposisi utama susu adalah air, lemak, protein, dan mineral (Muharastri, 2008). Adanya laktosa pada susu menyebabkan beberapa orang tidak bisa mengkonsumsi susu, dikarenakan alergi atau intoleran terhadap laktosa yang disebut dengan lactose intolerance. Salah satu produk yang karakteristiknya mendekati susu, dan aman bagi penderita penyakit lactose intolerance adalah susu nabati.

Susu nabati merupakan susu yang dibuat dari tumbuhan, terutama dari jenis kacang-kacangan dan serealia (Larosta,

*Korespondensi Penulis:

E-mail: ign.mayun@unud.ac.id
2019). Menurut Anggorodi (1994) laktosa hanya di produksi oleh kelenjar ambing, sehingga susu nabati tidak mengandung laktosa seperti susu yang berasal dari hewan. Susu nabati yang umum dikenal oleh masyarakat adalah susu kedelai, namun saat ini bermunculan susu nabati dengan bahan dasar kacang lainnya. Salah satunya adalah susu almond dengan bahan dasar almond. Almond memiliki kandungan gizi yang cukup tinggi, salah satunya adalah kandungan lemak yaitu sebanyak 49,4\% dengan tingkat asam lemak tak jenuh tunggal yang tinggi sebesar 67\%, yang bermanfaat bagi kesehatan jantung (Berryman et al., 2011). Kandungan lemak nabati yang cukup tinggi membuat almond memiliki cita rasa yang gurih (Damayanti dan Murtini, 2018). Selain lemak nabati, almond juga memiliki kandungan gizi lainnya yang cukup tinggi, diantaranya 
adalah vitamin E (25,63 $\mathrm{mg})$ dan serat (10,7 gram) dalam 100 gram almond (Anonimous, 2017). Setelah melalui proses pengolahan menjadi susu, susu almond memiliki kekurangan. Salah satunya adalah rendahnya kandungan protein pada susu almond.

Menurut Yetunde et al. (2013), kandungan protein yang dimiliki oleh susu almond adalah 1,70 gram per $100 \mathrm{ml}$. Kandungan protein yang dimiliki susu almond cukup rendah jika dibandingkan dengan susu nabati lainnya, sehingga perlu dilakukan penambahan bahan dengan kandungan protein yang lebih tinggi. Bahan tinggi protein yang bisa ditambahkan pada susu almond adalah kedelai. Menurut Damayanti dan Murtini (2018), penambahan sari kecambah kedelai pada susu almond dapat memenuhi persyaratan sebagai minuman sumber protein, berdasarkan syarat minimum pada kandungan lemak jenuh, natrium, dan protein.

Kedelai telah dikenal sebagai salah satu jenis kacang-kacangan dengan kadar protein tertinggi yaitu sekitar $30-40 \%$. Menurut Damayanti dan Murtini (2018) kadar protein kedelai cukup tinggi yaitu $30,44 \%$, jika bandingkan dengan jenis kacang-kacangan lain seperti kacang hijau $(23,86 \%)$, kacang merah $(23,58 \%)$, dan kacang tanah $(6,15 \%)$. Namun kedelai kuning memiliki kekurangan, salah satunya adalah rasanya yang kurang manis dibandingkan kedelai jenis lainnya yaitu edamame. Edamame adalah salah satu jenis kedelai dan termasuk dalam kelompok polong-polongan, serta dipanen pada puncak pemasakan sebelum mencapai masa pengerasan (Wahyuhapsari dan Agustin, 2013). Edamame dan kedelai kuning merupakan spesies yang sama, yaitu Glycine $\max (\mathrm{L}$.) Merrill, tetapi edamame memiliki rasa yang lebih manis, tekstur yang lebih lembut, dan biji yang berukuran lebih besar daripada kedelai kuning, serta nutrisi yang terkandung dalam edamame lebih mudah dicerna oleh tubuh dibandingkan kedelai kuning (Rackis, 1978). Edamame lebih mudah dicerna dikarenakan kandungan trypsin inhibitor yang lebih rendah dibandingkan yang ada pada kedelai kuning (Asadi, 2009). Edamame merupakan kedelai dengan kadar protein cukup tinggi, yaitu dalam 100 gram edamame mengandung 30,20 gram protein (Samsu, 2001).

Menurut Larosta (2019) semakin banyak perbandingan edamame yang digunakan, maka semakin tinggi kandungan protein pada susu jagung manis edamame, sehingga diharapkan dengan penambahan edamame pada susu almond dapat menghasilkan susu almond dengan kandungan protein yang mencukupi. Penelitian ini bertujuan untuk menetapkan perbandingan almond dan edamame yang tepat, sehingga menghasilkan susu almond edamame dengan karakteristik terbaik.

\section{METODE PENELITIAN Waktu dan Tempat}

Penelitian ini dilaksanakan pada bulan September - November 2019. Penelitian ini dilaksanakan di Laboratorium Pengolahan Pangan, Laboratorium Analisis Pangan, dan Laboratorium Rekayasa Proses dan Pengendalian Mutu, Program Studi Ilmu dan Teknologi Pangan, Fakultas Teknologi Pertanian, Universitas Udayana, Kampus Sudirman, Denpasar.

\section{Bahan dan Alat}

Bahan baku yang digunakan terdiri dari almond (Blue Diamond) yang diperoleh dari suplier bahan import, edamame varietas lokal yang diperoleh dari Pasar Badung, air mineral merek Aqua, dan CMC (Carboxy Methyl Cellulosa). Bahan kimia yang digunakan terdiri dari tablet kjeldahl, $\mathrm{H}_{2} \mathrm{SO}_{4}$ (PA), aquadest, $\mathrm{NaOH} 50 \%(\mathrm{PA})$, indikator $\mathrm{PP}$, asam borat, HCL (PA), dan heksan (teknis) yang didapat dari CV. Chem-Mix Pratama.

Alat yang digunakan untuk membuat produk terdiri dari timbangan digital, 
baskom, pisau, panci, gelas ukur, termometer, blender, kain saring, kompor, sendok makan dan sendok pengaduk. Alat yang digunakan untuk analisis terdiri dari oven, alat penyulingan, pemanas listrik, cawan porselin, neraca analitik, desikator, botol timbangan, pinggan penguap, pipet tetes, labu lemak, erlemeyer, gelas beker, soxhlet, tabung reaksi, gelas ukur, kertas saring, labu kjeldahl, $\mathrm{pH}$ meter, dan viscometer brookfield.

\section{Rancangan Percobaan}

Penelitian ini menggunakan Rancangan Acak Lengkap (RAL) dengan perlakuan perbandingan almond dan edamame yang terdiri dari 5 taraf, meliputi P0 (100\% almond : $0 \%$ edamame), P1 (90\% almond : $10 \%$ edamame), P2 (80\% almond : $20 \%$ edamame), P3 (70\% almond : $30 \%$ edamame), dan P4 (60\% almond : 40 $\%$ edamame). Perlakuan ini diulang sebanyak 3 kali sehingga diperoleh 15 unit percobaan. Data yang diperoleh dianalisis dengan sidik ragam dan perlakuan yang berpengaruh terhadap parameter yang diamati, dilanjutkan dengan uji Duncan (Steel dan Torrie, 1993).

\section{Parameter yang diamati}

Parameter yang diamati dalam penelitian ini adalah kadar protein metode Kjeldahl (SNI 01-2891-1992), kadar lemak metode hidrolisis (SNI 01-2891-1992), total padatan (SNI 01-3830-1995), viskositas dengan viscometer Brookfield, $\mathrm{pH}$ dengan pH meter, dan karakteristik sensoris secara hedonik dan skoring (warna, aroma, rasa dan penerimaan keseluruhan) (Soekarto, 1985).

\section{Pelaksanaan Penelitian}

\section{Perlakuan pendahuluan almond}

Proses perlakuan pendahuluan pada almond mengikuti penelitian yang dilakukan oleh Damayanti dan Murtini (2018) yang telah dimodifikasi. Almond disortasi, kemudian dicuci hingga bersih dan diberikan perlakuan steam blanching selama 25 menit pada suhu $\pm 80^{\circ} \mathrm{C}$ kemudian diangkat dan ditiriskan.

\section{Perlakuan pendahuluan edamame}

Proses perlakuan pendahuluan pada edamame dilakukan dengan sortasi edamame, kemudian di water blanching selama 8 menit pada suhu $\pm 80{ }^{\circ} \mathrm{C}$, kemudian dipisahkan biji dari kulitnya dan dicuci hingga bersih.

\section{Pembuatan susu almond edamame}

Pembuatan susu almond edamame mengacu pada penelitian yang dilakukan oleh Damayanti dan Murtini (2018) yang telah dimodifikasi. Almond dan edamame yang telah diberikan perlakuan pendahuluan, selanjutnya ditimbang sesuai dengan perlakuan yang telah ditentukan. Formula pembuatan susu almond edamame dapat dilihat pada Tabel 1.

Tabel 1. Formula pembuatan susu almond edamame

\begin{tabular}{|c|c|c|c|c|c|}
\hline \multirow{2}{*}{ Bahan - bahan } & \multicolumn{5}{|c|}{ Perlakuan } \\
\cline { 2 - 6 } & P0 & P1 & P2 & P3 & P4 \\
\hline Almond (g) & 150 & 135 & 120 & 105 & 90 \\
\hline Edamame (g) & 0 & 15 & 30 & 45 & 60 \\
\hline CMC (g) & 0,1 & 0,1 & 0,1 & 0,1 & 0,1 \\
\hline Air (ml) & 600 & 600 & 600 & 600 & 600 \\
\hline
\end{tabular}

Almond dan edamame yang telah ditimbang sesuai perlakuan, selanjutnya dimasukkan ke blender dan ditambah air 600 ml untuk digiling dengan blender selama 2 
menit. Bubur almond dan edamame yang diperoleh dari proses penggilingan tersebut selanjutnya disaring menggunakan kain saring dua lapis untuk mendapatkan filtratnya. Filtrat yang didapatkan disebut sebagai susu almond edamame, kemudian ditambahkan CMC dan dipasteurisasi selama 10 menit pada suhu $70^{\circ} \mathrm{C}$.
Selanjutnya dilakukan pengujian analisis sesuai parameter yang telah ditentukan.

\section{HASIL DAN PEMBAHASAN}

Nilai rata-rata kadar protein, kadar lemak, dan total padatan susu almond edamame dapat dilihat pada Tabel 2, dan nilai rata-rata viskositas dan $\mathrm{pH}$ susu almond edamame dapat dilihat pada Tabel 3.

Tabel 2. Nilai rata-rata kadar protein, kadar lemak, dan total padatan susu almond edamame.

\begin{tabular}{|c|c|c|c|}
\hline Almond : Edamame (\%) & Kadar Protein (\%) & Kadar Lemak (\%) & Total Padatan (\%) \\
\hline $100: 0$ & $3,59 \pm 0,50 \mathrm{~d}$ & $8,87 \pm 0,97 \mathrm{a}$ & $21,03 \pm 0,50 \mathrm{a}$ \\
\hline $90: 10$ & $4,66 \pm 0,41 \mathrm{c}$ & $7,39 \pm 0,46 \mathrm{~b}$ & $19,16 \pm 0,75 \mathrm{~b}$ \\
\hline $80: 20$ & $5,03 \pm 0,56 \mathrm{bc}$ & $6,85 \pm 1,01 \mathrm{bc}$ & $18,30 \pm 0,73 \mathrm{bc}$ \\
\hline $70: 30$ & $5,55 \pm 0,31 \mathrm{~b}$ & $6,41 \pm 0,32 \mathrm{bc}$ & $17,33 \pm 0,95 \mathrm{~cd}$ \\
\hline $60: 40$ & $6,39 \pm 0,19 \mathrm{a}$ & $5,57 \pm 0,34 \mathrm{c}$ & $16,52 \pm 0,89 \mathrm{~d}$ \\
\hline
\end{tabular}

Keterangan : Nilai rata-rata yang diikuti oleh notasi huruf yang berbeda pada kolom yang sama menunjukkan berpengaruh sangat nyata $(\mathrm{P}<0,01)$.

Tabel 3. Nilai rata-rata viskositas dan $\mathrm{pH}$ susu almond edamame.

\begin{tabular}{|c|c|c|}
\hline Almond : Edamame (\%) & Viskositas (cPs) & $\mathrm{pH}$ \\
\hline $100: 0$ & $506,67 \pm 89,63 \mathrm{a}$ & $6,43 \pm 0,06 \mathrm{~b}$ \\
\hline $90: 10$ & $416,67 \pm 35,12 \mathrm{ab}$ & $6,40 \pm 0,00 \mathrm{~b}$ \\
\hline $80: 20$ & $353,33 \pm 50,33 \mathrm{bc}$ & $6,40 \pm 0,10 \mathrm{~b}$ \\
\hline $70: 30$ & $293,33 \pm 41,63 \mathrm{c}$ & $6,50 \pm 0,00 \mathrm{ab}$ \\
\hline $60: 40$ & $246,67 \pm 50,33 \mathrm{c}$ & $6,57 \pm 0,06 \mathrm{a}$ \\
\hline
\end{tabular}

Keterangan : Nilai rata-rata yang diikuti oleh notasi huruf yang berbeda pada kolom yang sama menunjukkan berpengaruh sangat nyata $(\mathrm{P}<0,01)$.

\section{Kadar Protein}

Hasil sidik ragam kadar protein menunjukkan bahwa perbandingan almond dan edamame berpengaruh sangat nyata $(\mathrm{P}<0,01)$ terhadap kadar protein susu almond edamame. Data pada Tabel 2 menunjukkan kadar protein susu almond edamame terendah diperoleh dari perlakuan almond dan edamame $100 \%$ : $0 \%$ yaitu $3,59 \%$, sedangkan kadar protein tertinggi susu almond edamame diperoleh dari perlakuan almond dan edamame $60 \%$ :
$40 \%$ yaitu 6,39\%. Hasil penelitian menunjukkan semakin banyak perbandingan edamame pada susu almond edamame, maka kadar protein juga semakin meningkat. Hal ini disebabkan kadar protein edamame yang lebih tinggi dibandingkan almond, sehingga edamame merupakan sumber penyumbang protein tertinggi. Kandungan protein pada edamame adalah 30,20 gram dalam 100 gram bahan (Samsu, 2001), sedangkan kandungan protein pada almond adalah 21,43 gram dalam 100 gram bahan 
(Anonimous, 2017). Hal ini sesuai dengan penelitian sebelumnya yang dilakukan oleh Larosta (2019) pada pembuatan susu jagung manis edamame, yaitu semakin banyak perbandingan edamame yang digunakan maka semakin tinggi kandungan protein pada susu jagung manis edamame.

Hasil kadar protein pada perbandingan almond dan edamame $100 \%$ : $0 \%$ yaitu $3,59 \%$, berbeda dengan hasil yang didapatkan pada penelitian sebelumnya yang dilakukan oleh Yetunde et al. (2013) yaitu 1,70\%. Hal tersebut dapat disebabkan oleh adanya perbedaan jenis almond atau merk almond yang digunakan, perbedaan metode uji protein yang digunakan, dan perbedaan perlakuan pendahuluan pada almond yang digunakan pada penelitian ini. Menurut Damayanti dan Murtini (2018), perlakuan teknik steam blanching pada almond memberikan pengaruh nyata terhadap kenaikan kadar protein larut air dibandingkan dengan water blanching, sehingga teknik steam blanching digunakan sebagai perlakuan pendahuluan almond pada penelitian ini, untuk mengatasi kurangnya protein pada susu almond. Berdasarkan Standar Nasional Indonesia (SNI) nomor 01-38301995 tentang susu kedelai, kadar protein untuk susu kedelai adalah minimal 2\%, sehingga hasil penelitian menunjukkan semua perlakuan sudah memenuhi SNI, karena protein yang dihasilkan berkisar antara $3,59 \%-6,39 \%$.

\section{Kadar Lemak}

Hasil sidik ragam kadar lemak menunjukkan bahwa perbandingan almond dan edamame berpengaruh sangat nyata $(\mathrm{P}<0,01)$ terhadap kadar lemak susu almond edamame. Data pada Tabel 2 menunjukkan kadar lemak susu almond edamame terendah terdapat pada perlakuan almond dan edamame 60\%: $40 \%$ yaitu $5,57 \%$, sedangkan kadar lemak tertinggi susu almond edamame diperoleh pada perlakuan almond dan edamame 100\%: $0 \%$ yaitu $8,87 \%$. Data tersebut menunjukkan semakin banyak perbandingan edamame, maka kadar lemak susu almond edamame yang dihasilkan semakin rendah. Hal ini disebabkan oleh kandungan lemak pada almond yang tiga kali lebih tinggi dibandingkan dengan edamame. Kandungan lemak pada almond yaitu sebesar 50 gram dalam 100 gram bahan (Anonimous, 2017), dan kandungan lemak pada edamame sebesar 15,6 gram dalam 100 gram bahan (Samsu, 2001). Berdasarkan SNI nomor 01-3830-1995 tentang susu kedelai, kadar lemak susu kedelai adalah minimal $1 \%$, dan hasil penelitian susu almond edamame menunjukkan seluruh perlakuan sudah memenuhi SNI, karena lemak yang dihasilkan berkisar antara 5,57\% - 8,87\%.

\section{Total Padatan}

Hasil sidik ragam total padatan menunjukkan bahwa perbandingan almond dan edamame berpengaruh sangat nyata $(\mathrm{P}<0,01)$ terhadap total padatan susu almond edamame. Tabel 2 menunjukkan jumlah total padatan tertinggi susu almond edamame terdapat pada perlakuan almond dan edamame 100\% : 0\% yaitu $21,03 \%$, sedangkan total padatan terendah terdapat pada perlakuan almond dan edamame $60 \%$ : $40 \%$ yaitu $16,52 \%$. Data pada Tabel 2 menunjukkan semakin banyak perbandingan edamame, maka total padatan susu almond edamame yang dihasilkan semakin rendah. Hal tersebut dikarenakan edamame memiliki kandungan serat pangan yang sedikit lebih rendah dibandingkan almond yaitu 9,19\% (Cuenca et al., 2006) sedangkan kandungan serat pangan pada almond adalah 10,7\% (Anonimous, 2017). Total padatan yang menurun juga disebabkan oleh kandungan lemak pada almond yang tiga kali lebih tinggi dibandingkan edamame. Menurut Sentana dan Jatia 
(2017), kandungan lemak yang tinggi merupakan penyumbang utama total padatan dalam susu nabati.

Menurut Legowo dan Nurwantoro (2004), total padatan adalah padatan yang tersisa ketika kandungan air dalam bahan dihilangkan (diuapkan). Di dalam suatu bahan, sebagian padatan ada dalam bentuk terlarut dan sebagian yang lain tidak terlarut. Sehingga jenis dan jumlah padatan yang ada pada almond dan edamame sangat mempengaruhi total padatan pada susu almond edamame. Berdasarkan SNI nomor 01-3830-1995 tentang susu kedelai, total padatan untuk susu kedelai adalah minimal 11,50\%. Hasil penelitian menunjukkan seluruh perlakuan telah sesuai dengan SNI, karena hasil total padatan berkisar antara $16,52 \%-21,03 \%$.

\section{Viskositas}

Hasil sidik ragam viskositas menunjukkan bahwa perbandingan almond dan edamame berpengaruh sangat nyata $(\mathrm{P}<0,01)$ terhadap viskositas susu almond edamame. Data pada Tabel 3 menunjukkan viskositas terendah terdapat pada perlakuan almond dan edamame 60\% : $40 \%$ yaitu 246,67 cPs, sedangkan viskositas tertinggi terdapat pada perlakuan almond dan edamame 100\%:0\% yaitu 506,67 cPs. Hasil menunjukkan semakin banyak penambahan edamame maka viskositas susu almond edamame semakin menurun. Hal tersebut dikarenakan kadar air edamame yang cukup tinggi, yaitu 20 gram per 100 gram bahan (Samsu, 2001). Faktor lain yang menyebabkan viskositas susu almond edamame semakin menurun adalah total padatan. Menurut Sentana dan Jatia (2017), kadar total padatan yang semakin rendah menunjukkan kadar air susu nabati semakin tinggi. Akibat kadar air susu nabati yang semakin tinggi, maka susu nabati tersebut semakin cair sehingga viskositasnya akan menurun.
pH

Hasil analisis ragam untuk $\mathrm{pH}$ menunjukkan bahwa perbandingan almond dan edamame berpengaruh nyata $(\mathrm{P}<0,05)$ terhadap $\mathrm{pH}$ susu almond edamame. Pada Tabel 3 menunjukkan $\mathrm{pH}$ terendah terdapat pada perlakuan almond dan edamame $90 \%$ : $10 \%$ dan $80 \%$ : $20 \%$ yaitu 6,40 . Angka $\mathrm{pH}$ tertinggi terdapat pada perlakuan $60 \%$ : $40 \%$ yaitu 6,57. Semakin banyak edamame yang ditambahkan maka semakin tinggi $\mathrm{pH}$ pada susu almond edamame, hal tersebut dikarenakan $\mathrm{pH}$ pada edamame yang cukup tinggi yaitu 6,47 (Soleha et al., 2018).

Rendahnya kandungan trypsin inhibitor pada edamame juga mempengaruhi kandungan $\mathrm{pH}$, karena protein yang ada pada produk bisa terurai dengan baik akibat rendahnya kandungan trypsin inhibitor. Menurut Asadi (2009) Edamame lebih mudah dicerna dikarenakan kandungan trypsin inhibitor yang lebih rendah dibandingkan yang ada pada kedelai kuning. Menurut Deliana (2008) dalam Soleha et al., (2018), enzim proteolitik akan menyebabkan degradasi protein menjadi asam amino, sehingga jumlah nitrogen terlarut meningkat, degradasi protein ini juga menyebabkan peningkatan $\mathrm{pH}$. Berdasarkan SNI nomor 01-3830-1995 tentang susu kedelai, $\mathrm{pH}$ pada susu kedelai berkisar antara 6,5-7,0. Hasil penelitian susu almond edamame menunjukkan hanya ada dua perlakuan yang memenuhi SNI, yaitu pada perlakuan almond dan edamame $70 \%$ : 30\% yaitu 6,50 dan perlakuan almond dan edamame $60 \%: 40 \%$ yaitu 6,57 .

\section{Karakteristik Sensoris}

Nilai rata-rata uji hedonik (warna, aroma, rasa, dan penerimaan keseluruhan) dapat dilihat pada Tabel 4. Nilai rata-rata uji skoring warna susu almond edamame dapat dilihat pada Tabel 5, dan nilai rata-rata uji 
skoring terhadap aroma dan rasa susu almond edamame dapat dilihat pada Tabel 6.

Tabel 4. Nilai rata - rata uji hedonik warna, aroma, rasa, dan penerimaan keseluruhan susu almond edamame

\begin{tabular}{|c|c|c|c|c|}
\hline Almond : Edamame (\%) & Warna & Aroma & Rasa & $\begin{array}{c}\text { Penerimaan } \\
\text { Keseluruhan }\end{array}$ \\
\hline $100: 0$ & $5,10 \mathrm{a}$ & $5,45 \mathrm{a}$ & $4,90 \mathrm{a}$ & $4,80 \mathrm{a}$ \\
\hline $90: 10$ & $5,20 \mathrm{a}$ & $5,25 \mathrm{a}$ & $5,15 \mathrm{a}$ & $5,10 \mathrm{a}$ \\
\hline $80: 20$ & $5,40 \mathrm{a}$ & $5,35 \mathrm{a}$ & $5,10 \mathrm{a}$ & $5,10 \mathrm{a}$ \\
\hline $70: 30$ & $5,55 \mathrm{a}$ & $5,25 \mathrm{a}$ & $5,35 \mathrm{a}$ & $5,20 \mathrm{a}$ \\
\hline $60: 40$ & $5,60 \mathrm{a}$ & $5,40 \mathrm{a}$ & $5,05 \mathrm{a}$ & $5,85 \mathrm{a}$ \\
\hline
\end{tabular}

Keterangan : Nilai rata-rata yang diikuti oleh notasi huruf yang sama pada kolom yang sama menunjukkan berpengaruh tidak nyata $(\mathrm{P}>0,05)$.

$1=$ sangat tidak suka, 2=tidak suka, $3=$ agak tidak suka, 4=biasa, 5=agak suka, $6=$ suka, dan $7=$ sangat suka.

Tabel 5. Nilai rata-rata uji skoring warna susu almond edamame

\begin{tabular}{|c|c|}
\hline Almond : Edamame (\%) & Warna \\
\hline $100: 0$ & $5,00 \mathrm{a}$ \\
\hline $90: 10$ & $4,40 \mathrm{~b}$ \\
\hline $80: 20$ & $3,70 \mathrm{c}$ \\
\hline $70: 30$ & $2,90 \mathrm{~d}$ \\
\hline $60: 40$ & $2,35 \mathrm{e}$ \\
\hline
\end{tabular}

Keterangan : Nilai rata-rata yang diikuti oleh notasi huruf yang berbeda pada kolom yang sama menunjukkan berpengaruh sangat nyata $(\mathrm{P}<0,01)$.

$1=$ hijau, 2=putih sangat kehijauan, $3=$ putih kehijauan, $4=$ putih agak kehijauan, dan $5=$ putih

Tabel 6. Nilai rata-rata uji skoring aroma dan rasa susu almond edamame

\begin{tabular}{|c|c|c|}
\hline Almond : Edamame (\%) & Aroma & Rasa \\
\hline $100: 0$ & $3,85 \mathrm{a}$ & $3,75 \mathrm{a}$ \\
\hline $90: 10$ & $3,40 \mathrm{a}$ & $3,05 \mathrm{~b}$ \\
\hline $80: 20$ & $2,50 \mathrm{~b}$ & $2,35 \mathrm{c}$ \\
\hline $70: 30$ & $2,20 \mathrm{bc}$ & $2,00 \mathrm{~cd}$ \\
\hline $60: 40$ & $1,90 \mathrm{c}$ & $1,55 \mathrm{~d}$ \\
\hline
\end{tabular}

Keterangan : Nilai rata-rata yang diikuti oleh notasi huruf yang berbeda pada kolom yang sama menunjukkan berpengaruh sangat nyata $(\mathrm{P}<0,01)$.

$1=$ khas edamame, 2=agak khas edamame, 3=agak khas almond, 4=khas almond, dan 5=sangat khas almond

\section{Warna}

Hasil sidik ragam pada uji hedonik warna susu almond edamame menunjukkan, bahwa perbandingan almond dan edamame pada susu almond edamame berpengaruh tidak nyata $(\mathrm{P}>0,05)$. Data pada Tabel 4 menunjukkan nilai rata-rata uji hedonik warna berkisar antara 5,1 (agak suka) sampai dengan 5,6 (suka), sedangkan hasil sidik ragam pada uji skoring susu almond edamame menunjukkan, bahwa perbandingan almond dan edamame berpengaruh sangat nyata $(\mathrm{P}<0,01)$. Hal tersebut menunjukkan panelis rata-rata 
menyukai serta masih menerima perubahan warna yang terjadi setelah adanya perbedaan perlakuan pada susu almond edamame. Data pada Tabel 5 menunjukkan bahwa susu almond edamame yang memiliki perbandingan edamame lebih banyak, akan cenderung memiliki warna hijau akibat kandungan klorofil yang ada pada edamame.

\section{Aroma}

Hasil sidik ragam pada uji hedonik aroma susu almond edamame menunjukkan, bahwa perbandingan almond dan edamame pada susu almond edamame berpengaruh tidak nyata $(\mathrm{P}>0,05)$. Data pada Tabel 4 menunjukkan nilai rata-rata uji hedonik aroma berkisar antara 5,25 (agak suka) dampai dengan 5,45 (agak suka), sedangkan hasil sidik ragam pada uji skoring susu almond edamame menunjukkan, perbandingan almond dan edamame pada susu almond edamame berpengaruh sangat nyata $(\mathrm{P}<0,01)$. Hal tersebut menunjukkan panelis rata-rata agak menyukai aroma dari seluruh perlakuan susu almond edamame, dengan nilai rata-rata uji skoring berkisar antara 1,90 (agak khas edamame) sampai dengan 3,85 (khas almond).

\section{Rasa}

Pada uji hedonik rasa susu almond edamame, hasil sidik ragam menunjukkan bahwa perbandingan almond dan edamame berpengaruh tidak nyata $(\mathrm{P}>0,05)$. Data pada Tabel 4 menunjukkan nilai rata-rata uji hedonik berkisar antara 4,90 (agak suka) sampai dengan 5,35 (agak suka), sedangkan hasil sidik ragam pada uji skoring susu almond edamame menunjukkan bahwa perbandingan almond dan edamame berpengaruh sangat nyata $(\mathrm{P}<0,01)$. Hal tersebut menunjukkan panelis rata-rata agak menyukai rasa dari seluruh perlakuan, dengan nilai rata-rata uji skoring berkisar antara 1,55 (agak khas edamame) sampai dengan 3,75 (khas almond).

\section{Penerimaan Keseluruhan}

Hasil sidik ragam penerimaan keseluruhan susu almond edamame menunjukkan, perbandingan almond dan edamame berpengaruh tidak nyata $(\mathrm{P}>0,05)$. Data pada Tabel 4 menunjukkan, nilai ratarata uji hedonik terhadap penerimaan keseluruhan susu almond edamame berkisar antara 4,8 (agak suka) sampai dengan 5,85 (suka). Hal tersebut menunjukkan bahwa seluruh perlakuan perbandingan almond dan edamame pada susu almond edamame dapat diterima dengan baik oleh seluruh panelis.

\section{KESIMPULAN DAN SARAN Kesimpulan}

Berdasarkan hasil dan pembahasan penelitian maka dapat disimpulkan sebagai berikut.

1. Perbandingan almond dan edamame berpengaruh sangat nyata terhadap kadar protein, kadar lemak, total padatan, viskositas, $\mathrm{pH}$ dan uji skoring (warna, aroma, dan rasa), namun berpengaruh tidak nyata terhadap uji hedonik (warna, aroma, rasa, dan penerimaan keseluruhan) susu almond edamame.

2. Perbandingan almond dan edamame yang mampu menghasilkan susu almond dan edamame dengan karakteristik terbaik adalah $60 \%: 40 \%$ dengan hasil kadar protein 6,39\%, kadar lemak $5,57 \%$, total padatan $16,52 \%$, viskositas 246,67 cPs , dan pH 6,57. Hasil uji sensoris warna adalah putih sangat kehijauan (suka), aroma adalah agak khas edamame (agak suka), rasa adalah agak khas edamame (agak suka), dan penerimaan keseluruhan adalah suka.

\section{Saran}

Berdasarkan hasil penelitian sebaiknya dalam pembuatan susu almond edamame dibuat dengan perbandingan almond dan edamame $60 \%: 40 \%$, dan 
dilakukan penelitian lebih lanjut mengenai masa simpan susu almond edamame.

\section{DAFTAR PUSTAKA}

Anggorodi. 1994. Ilmu Makanan Ternak Umum. Gramedia, Jakarta.

Anonimous. 2017. Database for Raw Almond. USDA (United States Department of Agriculture). https://ndb.nal.usda.gov/ndb/search/lis t. Diakses pada tanggal 16 Juli 2019.

Asadi. 2009. Karakterisasi plasma nutfah untuk perbaikan varietas kedelai sayur (edamame). Buletin Plasma Nutfah. 15(2): $59-69$

Berryman C. E., A.G. Preston, W. Karmally, R. J. Deckelbaum, and P. M. KrisEitherton. 2011. Effects of almond consumption on the reduction of LDL Cholesterol: a discussion of potential mechanisms and future research directions. Nutrition Reviews:69: 171185.

Cuenca, R.A., M.J.Villanueva-Suárez, M.D.Rodríguez-Sevilla, and I.MateosAparicio. 2006. Chemical compotition and dietary fiber of yellow and green commercial soybeans (glycine max). Journal of Food Chemistry. 101 (2).

Damayanti, S. S., dan E. S. Murtini. 2018. Inovasi susu almond dengan substitusi sari kecambah kedelai sebagai sumber protein nabati. Jurnal Pangan dan Agroindustri. 6 (3): 70-77.

Deliana. 2008. Pengaruh Lama Fermentasi terhadap Kadar Protein, Lemak, Komposisi Asam Lemak dan Asam Fitat pada Pembuatan Tempe. Disertasi. Tidak dipublikasikan. Universitas Sumatera Utara, Medan.

Larosta, J. T. 2019. Pengaruh Perbandingan Jagung Manis dan Edamame terhadap Karakteristik Susu Jagung Manis
Edamame. Skripsi S1. Tidak dipublikasikan. Fakultas Teknologi Pertanian Unud, Denpasar.

Muhammad. 2002. Ilmu Ternak dan Pengolahan Pangan Edisi 1. Gramedia Pustaka, Yogyakarta.

Muharastri, Y. 2008. Analisis kepuasan konsumen susu UHT merek real good di kota Bogor. Skripsi S1. Tidak dipublikasikan. Fakultas Pertanian IPB, Bogor.

Rackis, J. J. 1978. Biochemical changes in soybeans: maturation.post-harvest storage and processing.and germination. H.O. Hultin and M. Milner (eds). Post-harvest Biology and Technology. Food and Nutrition.Hal: 34-76.

Samsu, H. S. 2001. Membangun Agroindustri Bernuansa Ekspor: Edamame (Vegetable Soybean). Graha Ilmu dan Florentina, Jember.

Sentana, A., C. Y. Trisnawatia, dan I. R. A. P. Jatia. 2017. Identifikasi Sifat Fisikokimia dan Organoleptik Susu Nabati yang Diformulasikan dengan Linear Programming. Fakultas Teknologi Pertanian. Universitas Katolik Widya Mandala, Surabaya.

Soekarto, S.T. 1985. Penilaian Organoleptik (untuk Industri Pangan dan Hasil Pertanian). Penerbit Bharata Karya Aksara, Jakarta.

Soleha M., J. M. Maligan, dan Yunianta. 2018. Pengaruh Penambahan Enzim Papain Terhadap Karakteristik Fisik, Kimia, dan Organoleptik Susu Kedelai (Kajian Jenis Kedelai dan Konsentrasi Enzim Papain). Jurnal Pangan dan Agroindustri. 6 (3): 18-29.

Wahyuhapsari, R., dan K. W. Agustin. 2013. Pembuatan miso dengan memanfaatkan edamame (kajian 
konsentrasi koji dan suhu inkubasi). Jurnal Pangan dan Agroindustri. Universitas Brawijaya, Malang.

Walstra P., J. T. M. Wouters, and T.J. Geurts. 2006. Dairy Science and Technology Handbook. Edisi kedua. Taylor and Francis Group, USA.

Yetunde A., Udofia, and S. Ukpong. 2013. Nutritional and sensory properties of almond seed milk. World Journal of Dairy and Food Sciences. 10: 117-1. 